\title{
Кольский филиал АН СССР: страницы истории ФИЦ КНЦ РАН
}

\section{Макарова Е.И.}

Hаучный архив ФИЦ КНЦ РАН, Anamumbl,makarova@admksc.apatity.ru

Аннотация. В 1949 г. был создан Кольский филиал АН СССР, ознаменовав переход кольской науки на новый этап развития, связанный с организацией новых институтов в системе Академии наук СССР и рождением новых научных направлений. Функционируя как научный комплекс с централизованным управлением системой научных и научно-вспомогательных объектов на всей территории Европейской Арктики четыре десятилетия Кольский филиал АН СССР в 1989 году был преобразован в Кольский научный центр АН СССР с переходом его институтов на самостоятельный баланс. Пройдя нелегкий пореформенный период 1990-х - 2000-х гг., Кольский научный центр в 2017 г. снова вернулся к необходимости централизованного управления в рамках Федерального исследовательского центра как наиболее оптимальной управленческой системы организации региональной науки.

Ключевые слова: Академия наук СССР, Кольская база АН СССР, Кольский филиал АН СССР, Первая послевоенная закрытая расширенная сессия Ученого совета Кольской научно-исследовательской базы им. С.М. Кирова АН СССР, Кольский научный центр АН СССР, Федеральный исследовательский центр Кольский научный центр.

\section{Kola Branch of the USSR AS: pages of FRC KSC RAS history}

Makarova E.I.

Scientific Archive FRC KSC RAS, Apatity, makarova@admksc.apatity.ru

\begin{abstract}
The Kola Branch of the USSR Academy of Sciences was established in 1949 to mark the turn of the Kola science to a new stage of its development. It was confined to establishing of new institutes in the USSR Academy of Sciences and development of new scientific fields. The Kola Branch of the USSR AS had been operating as a scientific complex with a centralized control over a system of scientific and scientific-subsidiary bodies over the whole European Arctic for 4 decades. In 1989 it was reorganized into the Kola Science Centre of the USSR AS, and its institutes became autonomous. After the challenging reforms in the 1990s-2000s, in 2017 the Kola Science Centre came back to the necessity of the centralized administration in the form of a Federal Research Centre as the most appropriate system of the regional science management.

Key words: USSR Academy of Sciences, Kola Station of the USSR AS, Kola Branch of the USSR AS, S.M. Kirov's The First Post-War Closed Extended Session of the Scientific Council of the Kola Scientific Research Station USSR AS, Kola Science Centre USSR AS, Federal Research Centre Kola Science Centre.

70 лет назад Постановлением Президиума АН СССР от 6 октября 1949 г. Кольская база АН СССР была реорганизована в Кольский филиал АН СССР, который просуществовал в этом статусе сорок лет до 1988 года.

Вглядываясь в историю промышленного освоения и урбанизации Европейского Севера России в XX столетии, мы видим свидетельства величайших преобразований общества и науки. Глубокие социальные преобразования сопровождались революцией в естествознании и рождением новых научных направлений. Среди имен ученых, прославивших отечественную науку в эпоху промышленного освоения Кольского Севера, значатся имена академика А.Е. Ферсмана, академика Д.С. Белянкина, академика А.В. Сидоренко, академика В.Т. Калинникова, академика Н.Н. Мельникова, академика Ф.П. Митрофанова, чл-корреспондента АН СССР Г.И. Горбунова, д.Г.м.н. Е.К. Козлова, д.г.м.н. И.В. Белькова - этот список можно продолжить и другими замечательными именами.

С их деятельностью, научной и организационной, связано рождение первого научного учреждения АН СССР в Арктике стационарного типа - Хибинской исследовательской горной станции - Кольской базы АН СССР и превращение ее в 1949 г. в комплексный исследовательский научный центр - Кольский филиал АН СССР. Кольский филиал АН СССР был создан 70 лет назад и успешно развивался четыре десятилетия до конца 1988 года как научный комплекс в форме централизован-
\end{abstract}


ного управления системой научных и научно-вспомогательных объектов на всей территории Европейской Арктики. В 1989 год Кольский филиал АН СССР вступил уже как Кольский научный центр АН СССР с переходом институтов Центра на самостоятельный баланс. Пройдя нелегкий пореформенный период 1990-х - 2000-х гг., Кольский научный центр в 2017 г. снова вернулся к необходимости централизованного управления в рамках Федерального исследовательского центра как наиболее оптимальной управленческой системы организации региональной науки.

70 лет спустя вспомним как это начиналось...

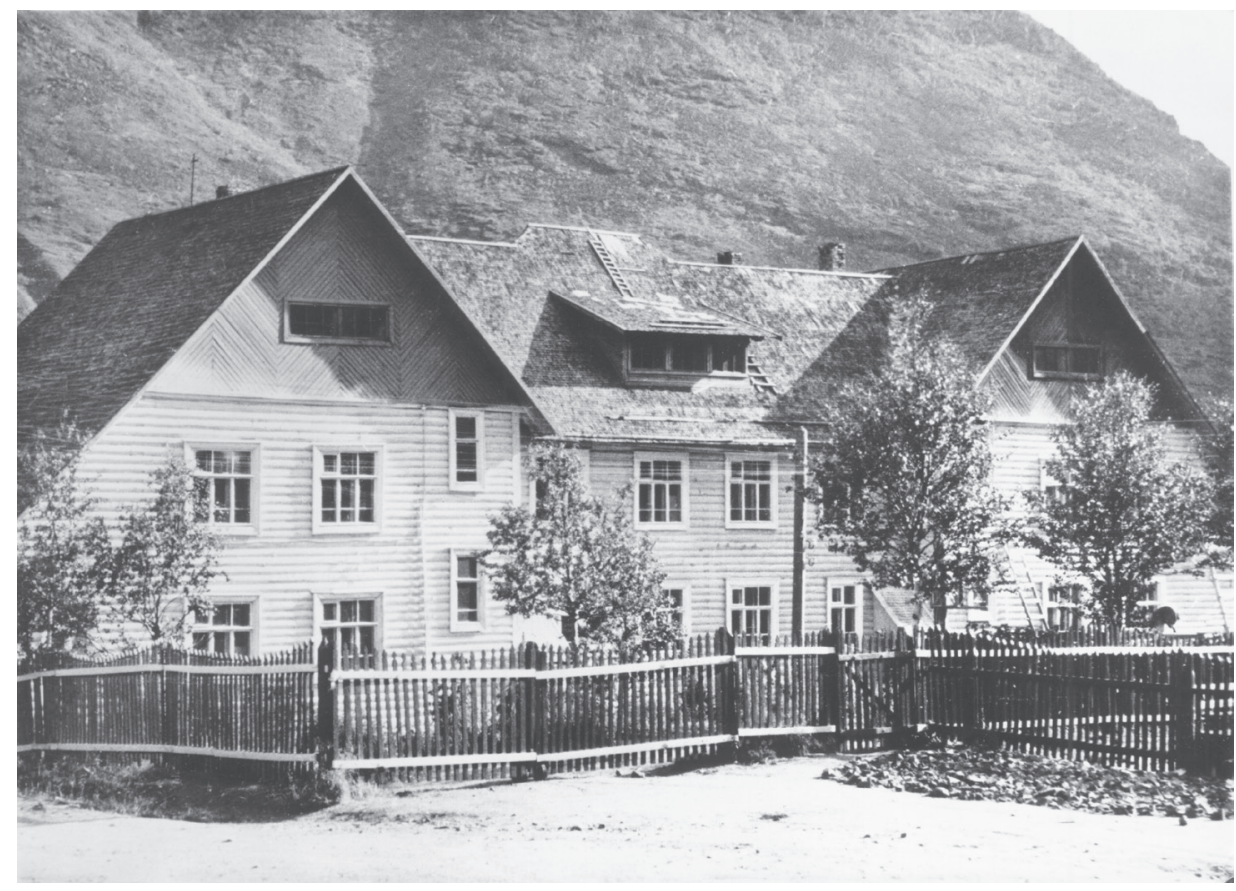

В 1948 г. официальным руководителем Базы был назначен академик Д.С. Белянкин. Тогда же на Кольском полуострове состоялась первая научная конференция послевоенного периода, запланированная А.Е. Ферсманом на сентябрь 1945 г. Первая послевоенная закрытая расширенная Сессия ученого совета Кольской базы им. С.М. Кирова АН СССР, проходила в Кировске с 10 по 15 июня 1948 г. и фактически ознаменовала наступление нового этапа в истории кольской науки, став точкой отсчета нового этапа индустриализации Мурмана (Макарова и др., 2017). Первый секретарь Мурманского обкома ВКП(б) А.М. Кутырев, нацеливая в своем докладе ученых на приоритеты новой жизни послевоенного периода Мурмана, сказал: «Мы рассчитываем, что возникнут и новые проблемы, подсказанные дальнейшим изучением недр области. Математические формулы со многими неизвестными не подходят для геологии, но чем больше мы будем знать, тем больше удастся восполнить пробелы между изученным и неизученным, ибо по современным геологическим данным даются прогнозы о возможности нахождения новых полезных ископаемых» (Макарова и др., 2017).

Через год Кольская база была преобразована в Кольский филиал АН СССР. Мурманская область вступила в новый период развития экономики, при этом состояние знаний о недрах региона затрудняло планирование развития производительных сил и формирование промышленных комплексов, вернувшихся из эвакуации и функционировавших в регионе. Область нуждалась в научном обеспечении активно развивающихся железорудной и горнодобывающей промышленности, базирующихся на освоении руд Ены и Оленегорска. Начал действовать Печенгский никелевый комбинат, уничтоженный во время войны, наращивал темпы добычи апатито-нефелиновой руды комбинат «Апатит». Предприятия нуждались в новых источниках сырья, и геологам предстояло найти их. Здесь требовался энтузиазм ученых и боевой задор молодых специалистов, приехавших на Кольский Север в послевоенный период. Особое место в истории кольской науки занимают ученые, 
пришедшие на Кольскую базу с полей войны. Сидоренко А.В., Бельков И.В., Воронков Н.А., Иванов А.М., Исаев С.И., Козлов Е.К., Кузнецов В.В., Курбатов С.С., Панасенко Г.Д., Сахаров А.С., Чумаков А.А. - благодаря их жизненному опыту, приобретенному в горниле войны, кольская наука внесла ускорение в реализацию задач, поставленных страной перед учеными в последующие послевоенные пятилетки.

В 1952 г. А.В. Сидоренко возглавил Кольский филиал АН СССР, к этому времени в структуре Филиала зародился и был учрежден первый научный институт - Геологический. Началось строительство Академгородка уже на территории Нового города - будущего г. Апатиты.

Интересно, что начальный проект Академгородка и одновременно центра будущего городановостройки предполагал совсем другой вид. В Научном архиве сохранились фотоматериалы предполагаемого проекта архитектора Г.И. Сорокина. В фотомакете новостройки предполагаемого центра города Апатиты угадываются черты сталинской социалистической эпохи с ее торжественностью и фундаметализмом. Но этот проект не получил путевку в жизнь - строительство осуществлялось уже при Н.С.Хрущеве, который как известно тяготел к простоте архитектурного замысла. Облик административного здания Кольского филиала был существенно упрощен, лишившись верхних этажей и башенок сверху. Не были построены и боковые здания с макета.

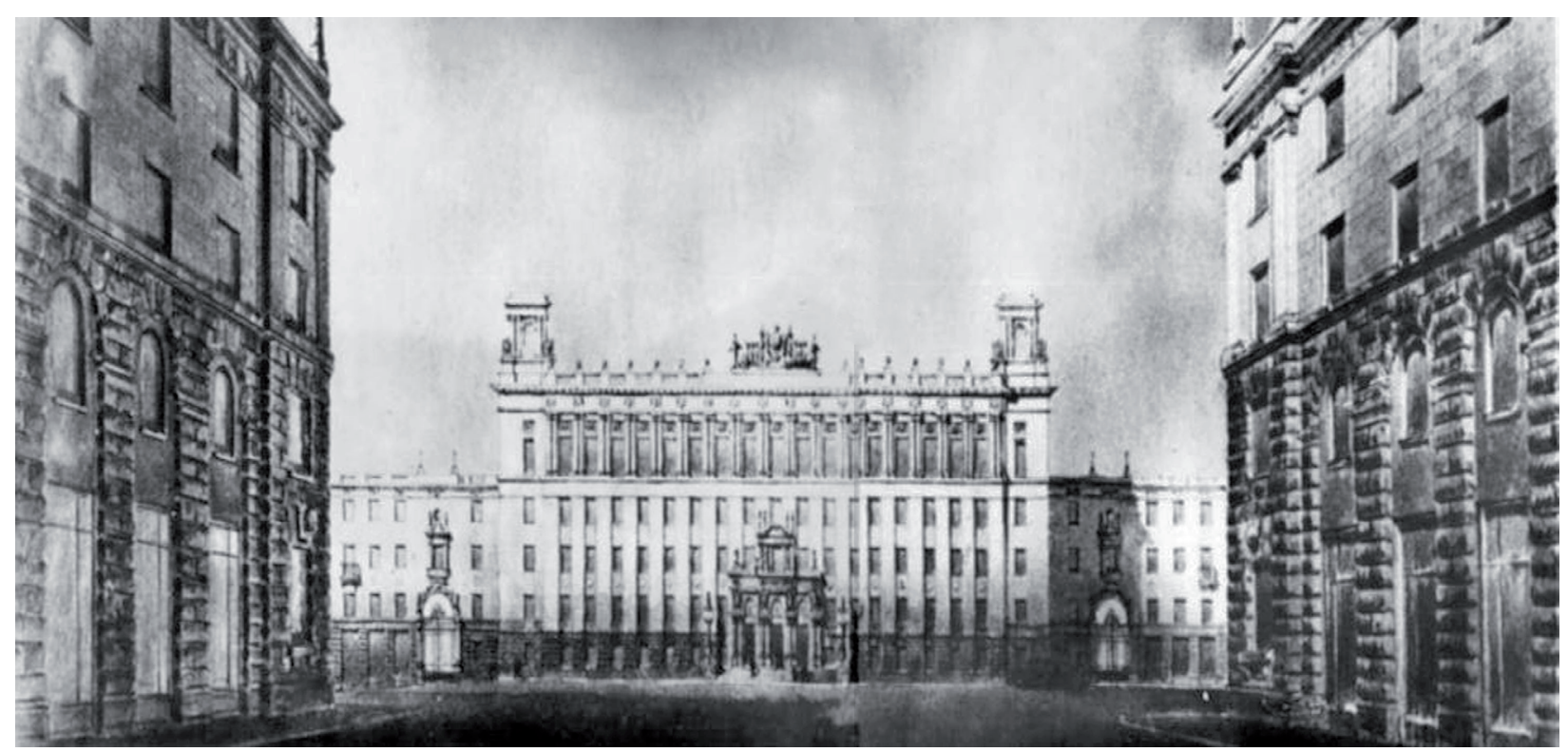

Панорама г. Апатиты приобрела совсем другой вид и решение:

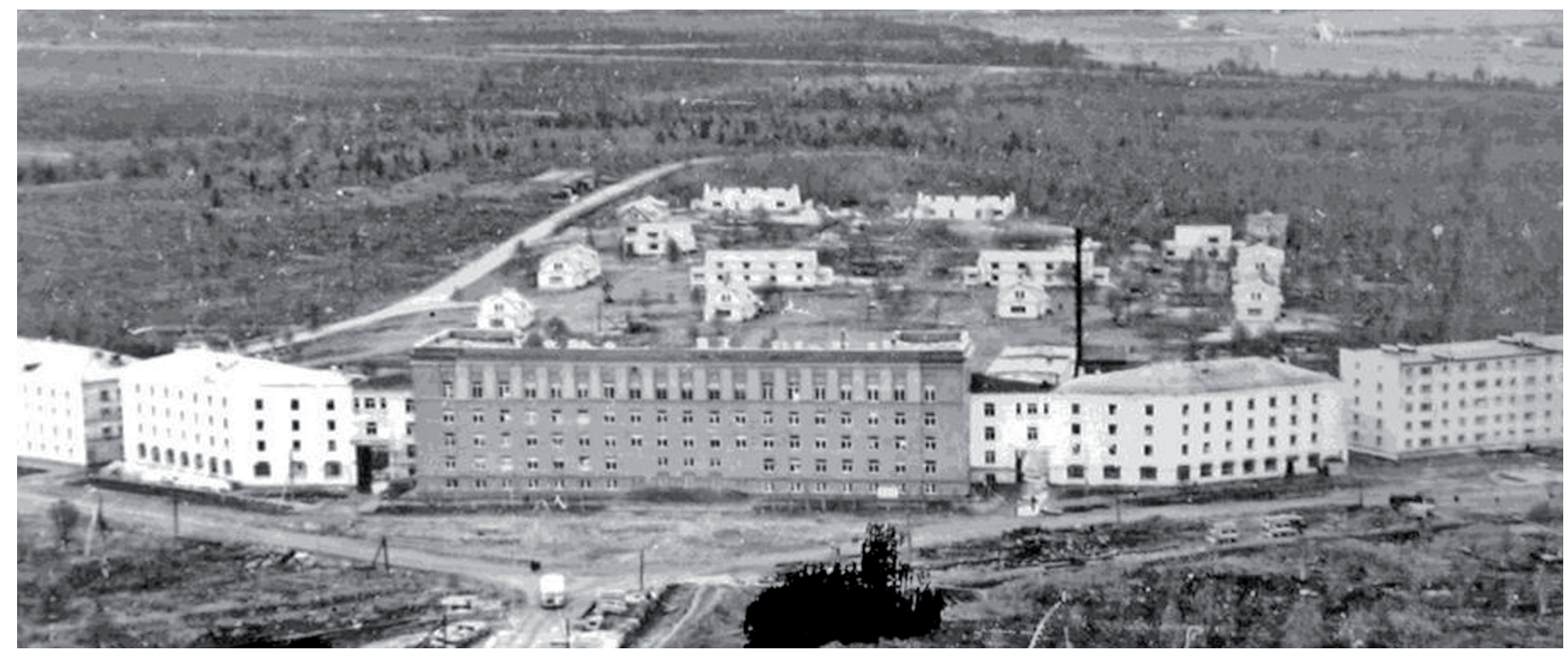


В 1960-е гг. Кольский филиал переехал в Новый город, Академгородок, несмотря на «хрущевскую» архитектурную реформацию, стал главной достопримечательностью и украшением рождающегося г. Апатиты, получившего свой статус в 1966 г. В Кировске на прежней территории оставался Полярно-альпийский ботанический сад-институт, с его уникальными коллекциями и особым статусом единственного ботанического научного подразделения в Заполярье, сохранявшегося вплоть до 1990-х гг.

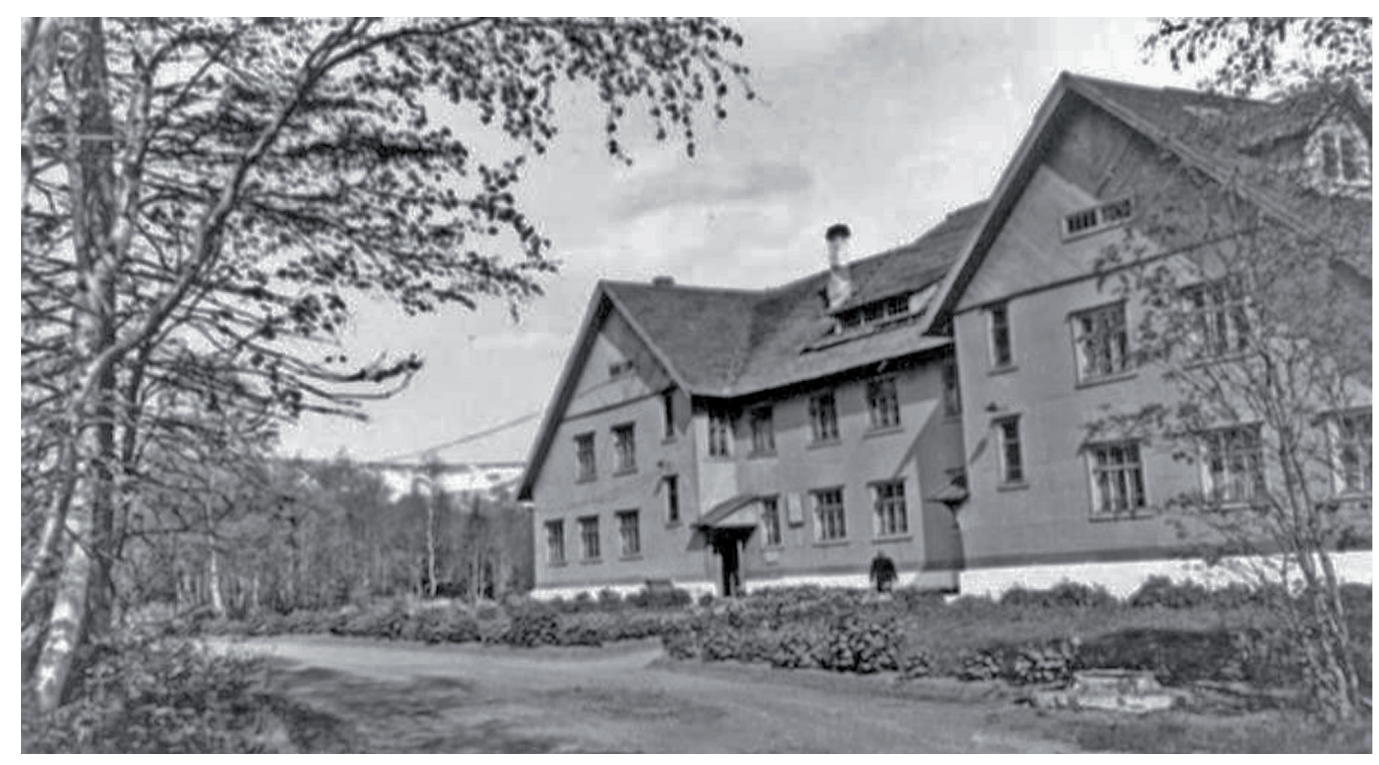

Постановлением Госкомитета Совмина СССР № 72 от 16 ноября 1967 г. Полярно-альпийский ботанический сад КФАН СССР в г.Кировске получил статус института в составе Кольского филиала АН СССР.

Академгородок активно расширялся: в 1967 г. был введен в эксплуатацию корпус Института химии и технологии редких элементов и минерального сырья КФАН СССР (ИХТРЭМС).

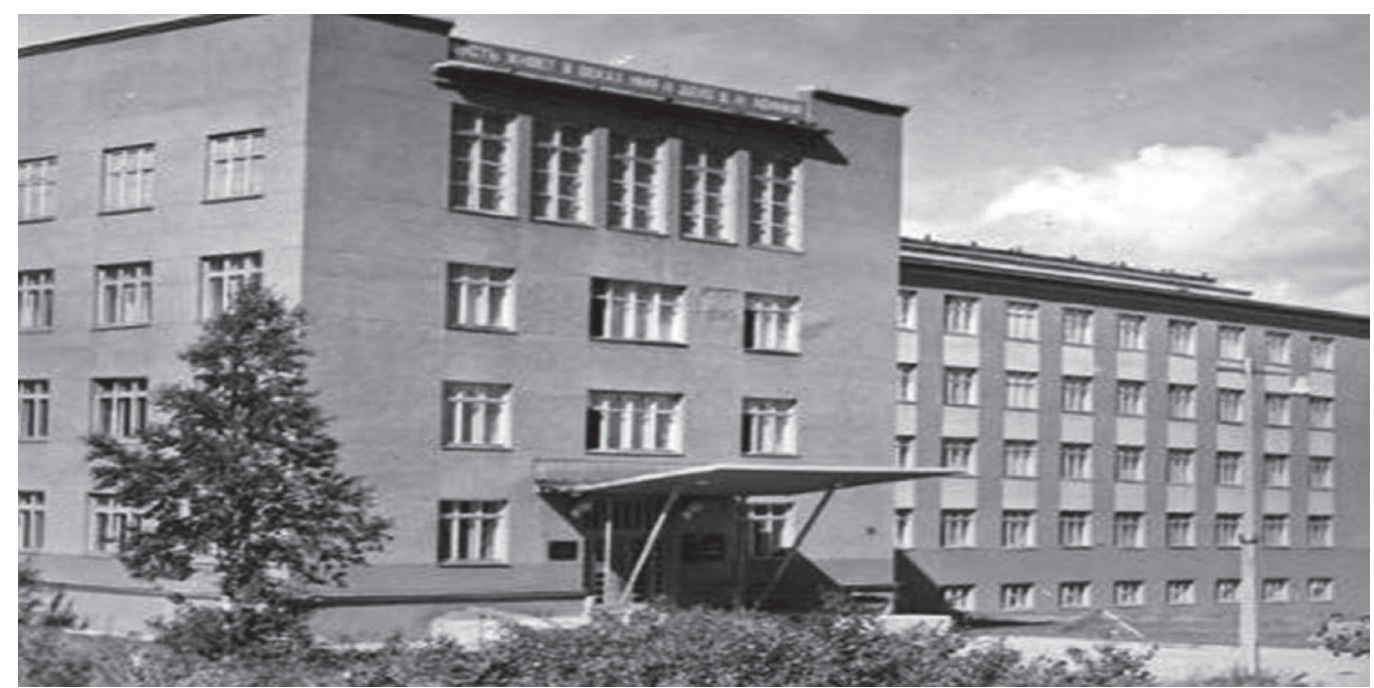

В августе 1970 г. введено в эксплуатацию здание Полярного геофизического института КФАН СССР - левое крыло здания ИХТРЭМС.

В декабре 1974 г. построено здание Горного института КФАН СССР, украсившее своим внушительным видом ул.Ферсмана, одну из центральных в г. Апатиты.

В сквере у Горного института в 1980-м г. академик А.В. Сидоренко торжественно открыл памятник академику А.Е. Ферсману. 

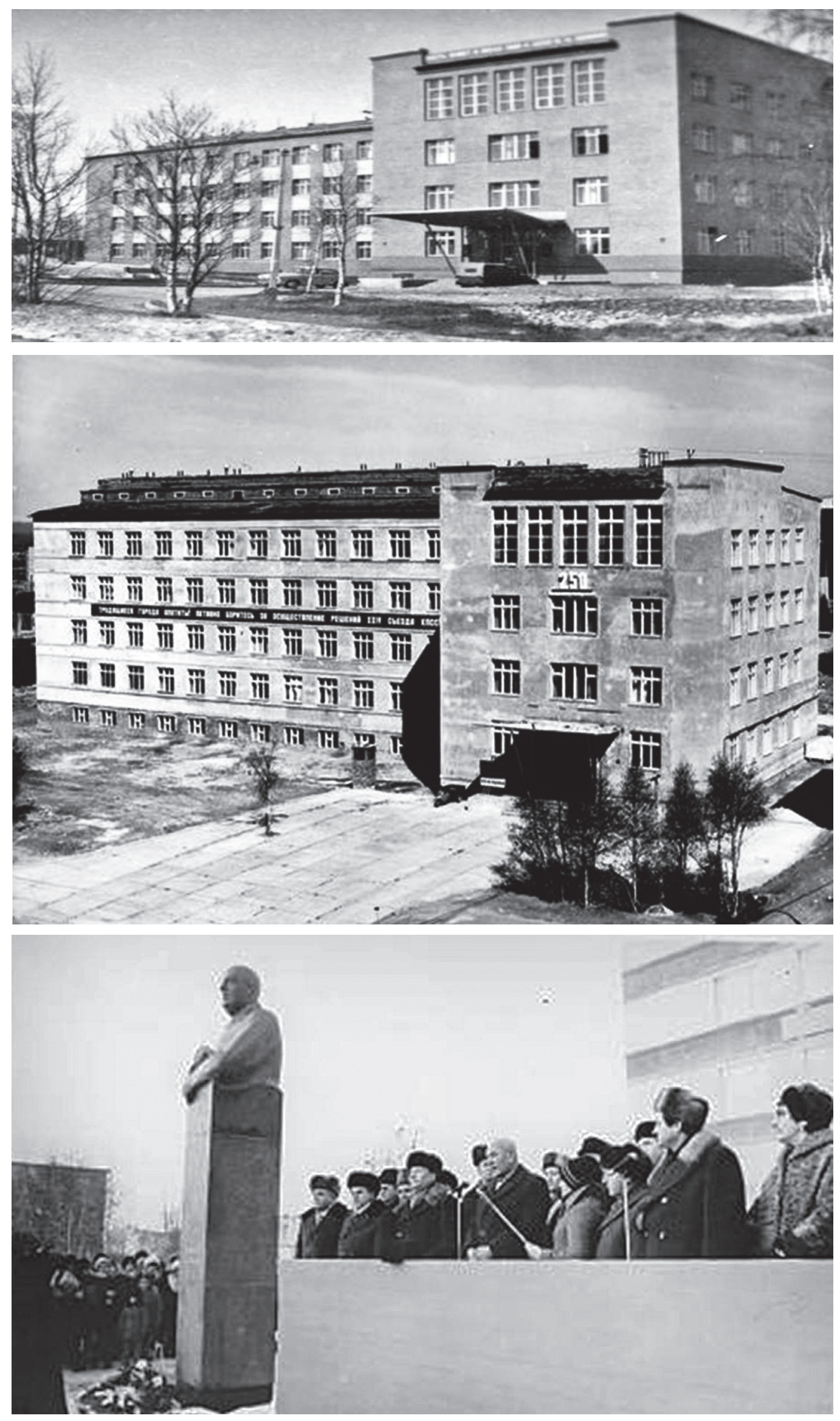
Затем в 1980-е гг. на территории Академгородка были построены: автобаза на 50 машин, 80-квартирный жилой дом, больница с поликлиникой, д/с на 140 мест, опытно-промышленная обогатительная установка, западная магистраль, новая АТС на 600 номеров, 4 км автодороги.

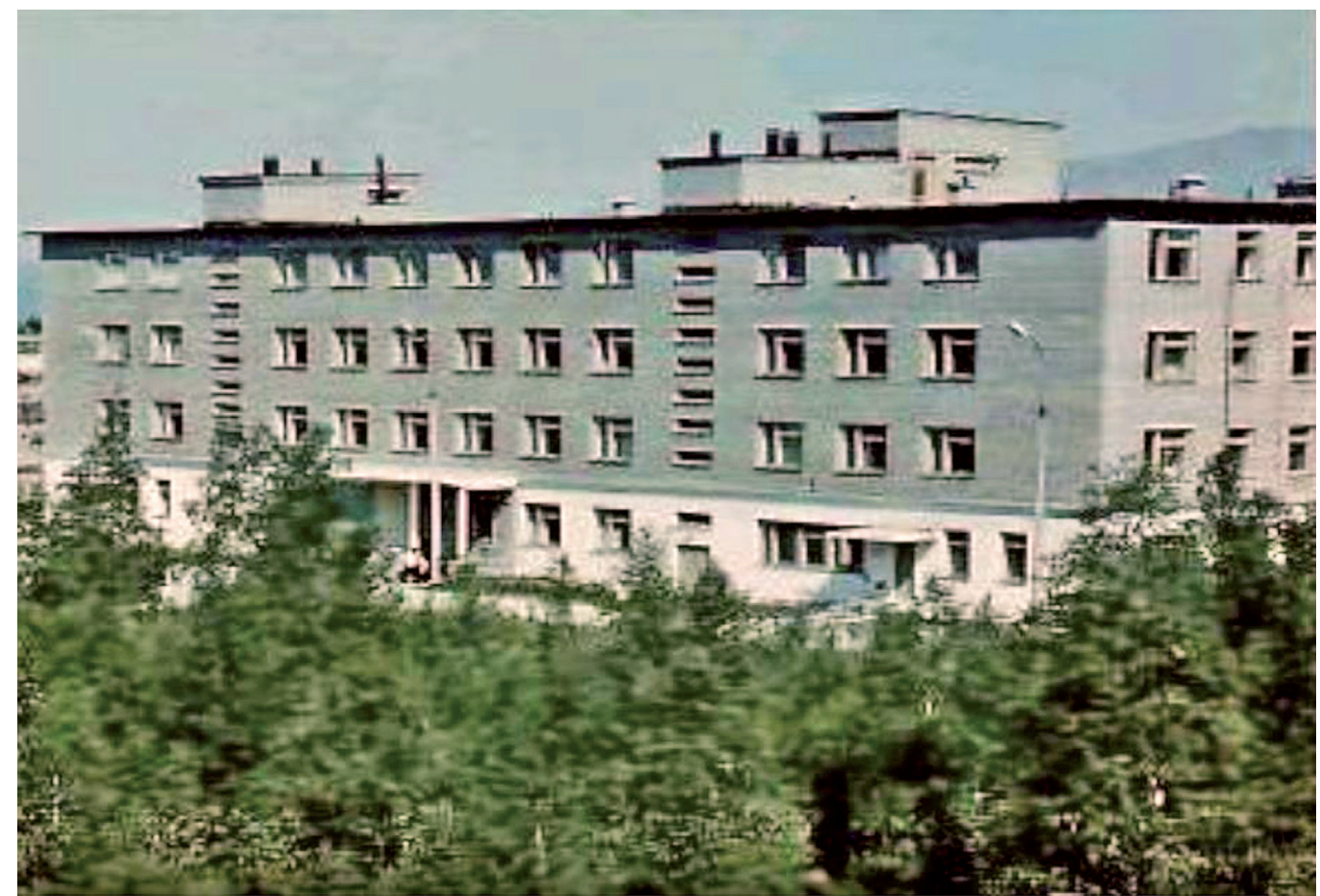

В 1982 г. на берегу озера Имандра был введен в экспуатацию санаторий-профилакторий «Имандра» для сотрудников Кольского филиала на 50 мест (ныне гостиничный комплекс «Тиетта»).

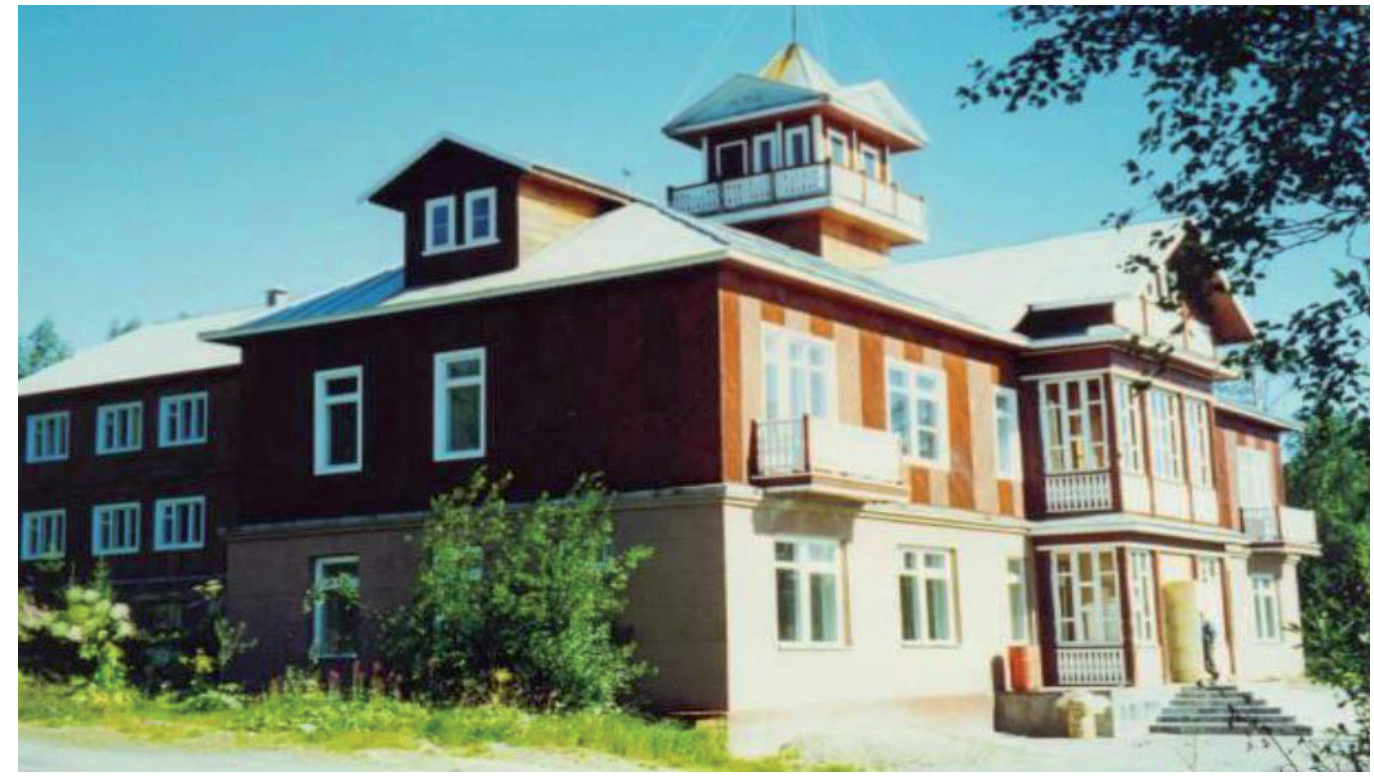

В 1983 г. в Академгородке появился первый в г.Апатиты спортивный комплекс «Наука».

Такое активное расширение Академгородка предполагало активизацию роста научных учреждений в составе КФАН СССР и было отнюдь не случайным явлением - Кольский филиала 27 сентября 1988 г. Постановлением Президиума АН СССР № 1113 Кольский филиал АН СССР преобразован в Кольский научный центр АН СССР(КНЦ АН СССР) на основании постановления ЦК КПСС и Совета Министров № 388 от 10 марта 1988 г. 


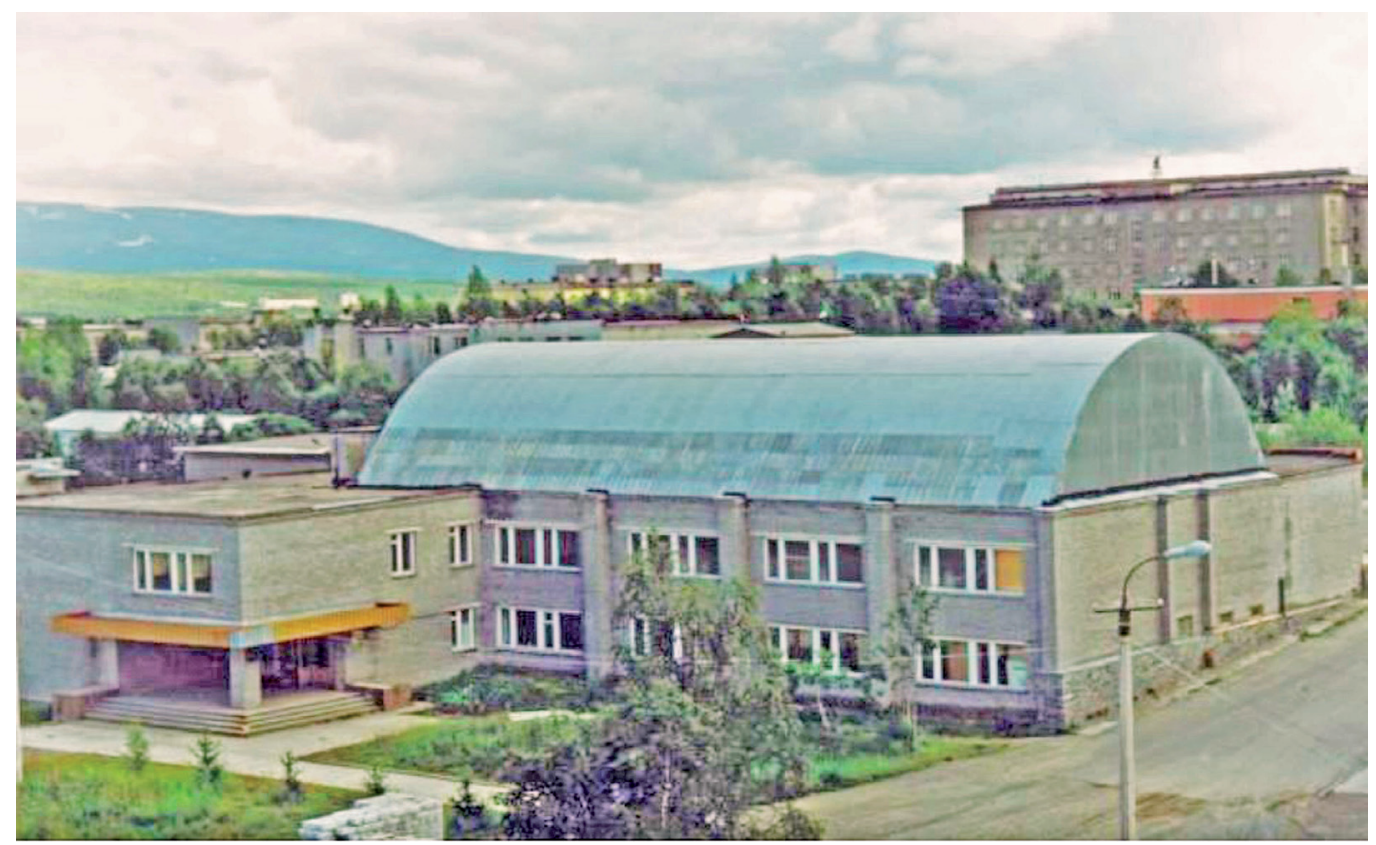

КНЦ АН СССР к этому времени по праву занимал ключевые позиции в координации научноисследовательских работ по региональным научно-техническим программам и интернациональным проектам в рамках Совета Баренц-региона. Расширилась структура КНЦ:

На базе Отдела экономических исследований в 1987 г. создан Институт экономических проблем Кольского филиала им. Кирова АН СССР. 31 января 1989 г.Постановлением Президиума АН СССР № 103 в составе Кольского научного центра АН СССР создан Институт информатики и математического моделирования технологических процессов. 27 июня 1989 г. Постановлением Президиума АН СССР № 577 в составе Кольского научного центра АН СССР создан Институт проблем промышленной экологии Севера. 10 сентября 1990 г. Постановлением Президиума АН СССР на базе Отдела энергетики создан Институт физико-технических проблем энергетики Севера Кольского научного центра РАН. Сентябрь 1991. Создан Кольский региональный сейсмологический центр КНЦ АН СССР(КРСЦ) на правах самостоятельного научного подразделения КНЦ

Политические перемены в стране и распад СССР повлияли на статус КНЦ - 21 ноября 1991г. Указом Президента РСФСР «Об организации Российской академии наук» Академия наук получила статус самоуправляемой научной организации. Кольский научный центр вошел в состав РАН как региональный научный центр.

В 2010 г. КНЦ РАН отметил свое 80-летие. Это было последнее совместное праздничное мероприятие институтов КНЦ, часть из которых, потеряв свою финансовую самостоятельность, вошла в состав КНЦ на правах научных подразделений, а часть вышла из состава КНЦ.

В следующее 10-летие КНЦ РАН вступил в новую волну реформ и преобразований: в 2013 году был передан из РАН под управление ФАНО России, под эгидой которого прошел путь реформирования, завершившийся в 2017 году образованием Федерального исследовательского центра под руководством член-корреспондента РАН С.В. Кривовичева и переходом в 2018 году под управление Министерства науки и высшего образования. Так Кольский научный центр в 2017 г. в рамках Федерального исследовательского центра вернулся к форме централизованного управления как «наиболее оптимальной управленческой системы организации региональной наук».

Сегодня ФИЦ КНЦ РАН - это комплексное научное учреждение, включающее 10 институтов. В его структуре трудятся более 440 исследователей: 222 кандидата наук; 57 докторов наук, среди которых - 177 молодых ученых (в возрасте до 39 лет). ФИЦ КНЦ РАН осуществляет фундаментальные исследования особенностей природной среды Евро-Арктического региона и обеспечивает научную основу для оценки его ресурсного потенциала с целью разработки рациональной стратегии освоения северных территорий. Новый этап истории существования ФИЦ КНЦ РАН 
С.В. Кривовичев характеризует как время больших перемен: «Новое время ставит новые задачи перед страной, перед правительством, перед Российской академией наук. <...> Впереди большие задачи - укрепить и нарастить научный и технический потенциал, усилить старые и создать новые точки роста в области науки и технологий, обновить кадровый состав молодыми талантливыми исследователями. Мы открыты к сотрудничеству со всеми и будем работать на благо нашей Родины, - к этому нас обязывает наше прошлое - славные традиции Российской академии наук, традиции Кольского научного центра. Вперед - к новым научным достижениям, интересным и важным результатам, новым изобретениям и технологиям!» (Кривовичев С.В., 2018).

\section{Литература}

1. Макарова Е.И., Петров В.П., Токарев А.Д. Советский опыт научного сопровождения освоения природных ресурсов Кольского Севера в 1-й половине XX века // «После Октябрьской революции. События и судьбы в истории Кольского Севера 1-ой половины XX века». К 100-летию Великой российской революции. Материалы научно-практической конференции. 20 октября 2017 г. Кировск, 2017. С. 30-35.

2. Макарова Е.И., Петров В.П., Токарев А.Д. История послевоенного развития академической науки по материалам послевоенных сессий Ученого совета Кольской базы АН (1948-1949 гг.) // Труды Кольского научного центра РАН, Гуманитарные исследования. 4/2017 (8). Вып. 11. Апатиты. 2017. С. 14-35.

3. https://www.ksc.ru/o-tsentre/. 